\title{
Inhibition of oxidative stress-induced invasiveness of cancer cells by Ganoderma lucidum is mediated through the suppression of interleukin-8 secretion
}

\author{
ANITA THYAGARAJAN ${ }^{1}$, JIAHUA JIANG $^{1}$, AMBER HOPF $^{2}$, JIRI ADAMEC $^{2}$ and DANIEL SLIVA ${ }^{1,3,4}$ \\ ${ }^{1}$ Cancer Research Laboratory, Methodist Research Institute, 1800 N Capitol Ave, E504, Indianapolis, IN 46202; \\ ${ }^{2}$ Bindley Bioscience Center, Purdue University, West Lafayette, IN; ${ }^{3}$ Department of Medicine, and \\ ${ }^{4}$ Indiana University Cancer Center, School of Medicine, Indiana University, Indianapolis, IN, USA
}

Received February 23, 2006; Accepted April 19, 2006

\begin{abstract}
Epidemiological studies suggest that the intake of natural/nutrient products is inversely related to cancer risk. While oxidative stress, generating reactive oxygen species, has been linked to cancer initiation and progression, dietary antioxidants have reduced the risk of certain cancers. Experimental studies have demonstrated that antioxidants and phytochemicals could prevent cancer metastasis, and antioxidants were suggested as adjuvants in cancer therapy. Ganoderma lucidum is an Asian medicinal mushroom that has been used for the past two thousand years for the treatment of various diseases, including cancer. G. lucidum is currently popular as a dietary supplement in the form of tea, powder or extract. We have previously demonstrated that G. lucidum suppresses growth, angiogenesis and invasiveness of highly invasive and metastatic breast cancer cells. The present study was undertaken to evaluate the effect of G. lucidum on oxidative stress-induced metastatic behavior of poorly-invasive MCF-7 breast cancer cells. We show that $G$. lucidum inhibits oxidative stressinduced migration of MCF-7 cells by the down-regulation of MAPK signaling. G. lucidum suppressed oxidative stress stimulated phosphorylation of extracellular signal-regulated protein kinases (Erk1/2), which resulted in the down-regulation of expression of c-Fos, and in the inhibition of transcription factors AP-1 and NF-кB. The biological effect of G. lucidum on cell migration was mediated by the suppression of secretion of interleukin-8 from MCF-7 cells exposed to oxidative stress. In summary, our results suggest that G. lucidum inhibits the oxidative stress-induced invasive behavior of breast cancer cells by modulating Erk1/2 signaling and can be potentially considered as an antioxidant in adjuvant cancer therapy.
\end{abstract}

Correspondence to: Dr D. Sliva, Cancer Research Laboratory, Methodist Research Institute, $1800 \mathrm{~N}$ Capitol Ave, E504, Indianapolis, IN 46202, USA

E-mail: dsliva@clarian.org

Key words: Ganoderma lucidum, breast cancer, oxidative stress, AP-1, NF-кB, IL-8

\section{Introduction}

Breast malignancy usually progresses from non-invasive cancer to invasive, metastatic and therapy-resistant phenotype. Therefore, the highly invasive behavior of breast cancer cells results in the development of cancer metastasis, which was responsible for more than 40,000 breast cancer deaths in the United States in 2005 (1). Oxidative stress, which is mediated by reactive oxygen species (ROS), drives cancer initiation and progression through mutations caused by DNA damage, and is involved in promotion of the angiogenesis and metastasis of breast cancer (2). Therefore, oxidative stress induces production of angiogenic factors, such as vascular endothelial growth factor (VEGF) and interleukin-8 (IL-8), by cancer cells (3). Besides the metastasis supported by the growth of new blood vessels, oxidative stress may also promote metastasis through the stimulation of migration of cancer cells (2). Migration of a variety of cells, including endothelial cells, keratinocytes and melanocytes, is induced by IL-8, which demonstrates strong chemotactic activity (4-6). In addition, overexpression of IL-8 was detected in breast cancer tissues and correlated with a highly invasive potential and metastatic phenotype of breast cancer cells (7-10). Therefore, the inhibition of IL-8 could be therapeutically important for the inhibition of invasion and metastasis of breast cancer.

The expression of IL- 8 is regulated by a variety of transcription factors, including hepatocyte nuclear factor-1, interferon regulatory factor-1, activator protein-1 (AP-1), CCAAT/enhancer binding protein $(\mathrm{C} / \mathrm{EBP})$ and nuclear factor- $\mathrm{B}(\mathrm{NF}-\kappa \mathrm{B})$, by different stimuli in a cell-specific manner $(11,12)$. AP-1 and $\mathrm{NF}-\kappa \mathrm{B}$ were identified as major regulators of physiological as well as pathological conditions, including cancer $(13,14)$. Although oxidative stress induced AP-1 activity in tamoxifene-resistant breast tumors (15), and antioxidants suppressed ROS-induced activation of AP-1 and $\mathrm{NF}-\kappa \mathrm{B}$ in prostate cancer cells (16), the mechanisms of ROSdependent activation or inhibition of AP-1 and NF- $\mathrm{KB}$ in cancer development remain to be elucidated $(17,18)$. Epidemiological studies show that the consumption of food rich in antioxidants is inversely related to cancer risk (19), and experimental studies further demonstrate that dietary 
antioxidants can selectively kill cancer cells in vitro and can inhibit tumor angiogenesis and metastatic growth in vivo (20).

Ganoderma lucidum has been used as a diet therapy in traditional Chinese medicine for several millennia. Although a wide variety of bioactive molecules have been identified in this medicinal mushroom, its anticancer effects are predominantly described with polysaccharide and/or triterpene fractions (21). In addition to modulation of the immune system (22), polysaccharide fractions from $G$. lucidum also demonstrated antioxidant properties (23-25). Antioxidative activity was also identified in triterpene fraction containing ganoderic acid A (26). In the present study, we evaluated the effect of G. lucidum on the oxidative stress-induced invasiveness of breast cancer cells. We describe the possible mechanism of the inhibition of oxidative stress-stimulated IL- 8 secretion and migration of breast cancer cells by G. lucidum.

\section{Materials and methods}

Materials. G. lucidum extract, containing $13.5 \%$ polysaccharides and $6 \%$ triterpenes, was obtained from Pharmanex LLC (Provo, UT). This extract was dissolved in sterile water at a concentration of $50 \mathrm{mg} / \mathrm{ml}$ and stored at $4^{\circ} \mathrm{C}$. Ganoderic acid $\mathrm{A}, \mathrm{F}$, and $\mathrm{H}$ were purchased from Chromadex (Santa Ana, CA).

Cell culture. Human breast cancer cells, MCF-7, were obtained from ATCC (Manassas, VA) and maintained in Dulbecco's modified Eagle's medium (DMEM) containing penicillin (50 U/ml), streptomycin $(50 \mathrm{U} / \mathrm{ml})$, and $10 \%$ fetal bovine serum (FBS). Media and supplements were from Invitrogen (Grand Island, NY). FBS was obtained from Hyclone (Logan, UT).

Lipid peroxidation assay. MCF-7 cells $\left(5 \times 10^{7}\right)$ were treated with $5 \mathrm{mM} \mathrm{H}_{2} \mathrm{O}_{2}$ and $G$. lucidum extract $(0-0.5 \mathrm{mg} / \mathrm{ml})$ for $24 \mathrm{~h}$. Lipid peroxidation was performed with malondialdehyde (MDA) and N-methyl-2-phenylindole (NMPI) according to the manufacturer's instructions (BioOxytech MDA-586, OXIS International, Inc., Portland, OR). Amounts of cellular products of lipid peroxidation were measured spectrophotometrically at $586 \mathrm{~nm}$.

Western blot analysis. Whole cell extracts were prepared from MCF-7 cells treated with $\mathrm{H}_{2} \mathrm{O}_{2}(0-5 \mathrm{mM})$ and G. lucidum extract $(0-0.5 \mathrm{mg} / \mathrm{ml})$ as previously described (27). Equal amounts of proteins ( $20 \mu \mathrm{g} / \mathrm{lane})$ were separated on NuPAGE 4-12\% Bis-Tris gel (Invitrogen, Carlsbad, CA) and transferred to a PVDF membrane (Millipore, Bedford, MA). Protein expression was detected with the corresponding primary antibodies: anti-Erk1/2, anti-phospho-Erk1/2 (Cell Signaling, Beverly, MA), anti-c-Jun, anti-c-Fos and anti- $\beta$-actin antibody (Santa Cruz Biotechnology, Santa Cruz, CA), respectively. Protein expression was visualized using the ECL Western blotting detection system (Amersham Biosciences, Buckinghamshire, UK).

DNA-binding assay. MCF-7 cells were treated with $\mathrm{H}_{2} \mathrm{O}_{2}$ $(5 \mathrm{mM})$ and G. lucidum extract $(0-0.5 \mathrm{mg} / \mathrm{ml})$, nuclear proteins were prepared and DNA-binding assay with ${ }^{32} \mathrm{P}-$ labeled AP-1 and ${ }^{32} \mathrm{P}$-labeled NF-кB was performed as previously described (28). Oligonucleotide probes containing consensus sequence for AP-1 and NF-kB were purchased from Promega (Madison, WI).

DNA transfection and reporter gene assays. MCF-7 cells were transiently transfected with AP-1-Luc or NF-кB-Luc reporter constructs (BD Biosciences, CA, USA) and B-galactosidase expression vector, $\mathrm{pCH} 110$, as previously described (28). The cells were treated with $G$. lucidum extract for $24 \mathrm{~h}$, followed by oxidative stress with $\mathrm{H}_{2} \mathrm{O}_{2}$ for an additional 4 and $6 \mathrm{~h}$. The cell lysates were prepared and $\mathrm{B}$-galactosidase determined as previously described (28). The luciferase activity was determined in samples containing equal units of $\beta$-galactosidase in luciferase assay buffer (4 mM EGTA, $15 \mathrm{mM} \mathrm{MgSO}_{4}, 25 \mathrm{mM}$ Glycylglycine $\mathrm{pH} 7.8,15 \mathrm{mM}$ potassium phosphate $\mathrm{pH} 7.8$, $2 \mathrm{mM}$ ATP, $1 \mathrm{mM}$ DDT) with the luciferin solution $(200 \mu \mathrm{M}$ D-luciferin, $25 \mathrm{mM}$ Glycylglycine $\mathrm{pH}$ 7.8, 2 mM DTT) by using Lmax luminometer (Molecular Devices, CA, USA) Data points represent the average \pm S.D. of 3-6 independent transfection experiments.

ELISA analysis. MCF-7 cells were treated with $\mathrm{H}_{2} \mathrm{O}_{2}(5 \mathrm{mM})$ and with $G$. lucidum extract $(0-0.5 \mathrm{mg} / \mathrm{ml})$, for $24 \mathrm{~h}$, cell media were collected and the secretion of IL- 8 was determined using an IL-8 Quantikine human immunoassay kit (R\&D Systems, Minneapolis, $\mathrm{MN}$ ), according to the manufacturer's instructions.

Cell migration assay. Chemotaxis was induced by conditioned media from MCF-7 exposed to oxidative stress and G. lucidum extract was assessed and evaluated by modified cell migration protocol (29). Briefly, media from the MCF-7 cells treated with $G$. lucidum and $\mathrm{H}_{2} \mathrm{O}_{2}$ were collected and concentrated with YM-10 concentrating filtering devices (Millipore, MA, USA). Chemotaxis was assessed after $96 \mathrm{~h}$ of incubation as we previously described (29). Data points represent the average \pm S.D. of three individual filters within one representative experiment repeated at least twice.

Sample preparation for LC-MS analysis. G. lucidum, dissolved in water $(50 \mathrm{mg} / \mathrm{ml})$, was extracted for $1 \mathrm{~h}$ at room temperature, and filtrated using a $0.45-\mu \mathrm{m}$ filter. The samples were prepared by diluting $100 \mu \mathrm{l}$ of extract with $900 \mu \mathrm{l}$ of $50 \%$ methanol containing $1 \%$ acetic acid. Oasis HLB 1cc extraction cartridges (Waters) were conditioned with $1 \mathrm{ml} 100 \%$ methanol and equilibrated with $1 \mathrm{ml} 50 \%$ methanol containing $1 \%$ acetic acid. Each sample was loaded and washed with $1 \mathrm{ml} 50 \%$ methanol containing $1 \%$ acetic acid. The samples were eluted with $1 \mathrm{ml} \mathrm{100 \%}$ methanol acidified with $1 \%$ acetic acid and evaporated to dryness in a speed vacuum system. The samples were resuspended in $100 \mu \mathrm{l}$ of $25 \%$ methanol containing $0.1 \%$ formic acid for LC-ESI-MS analysis.

LC-ESI-MS. Standards of ganoderic acid A, F and $\mathrm{H}$ and the samples of G. lucidum were separated on a capillary HPLC system (1100 Series LC, Agilent). After injection the compounds were concentrated on a MicroBore SB-C-18 enrichment column (1x17 mm, Agilent) and washed with 3\% acetonitrile; $0.01 \%$ TFA at flow rate $20 \mu \mathrm{l} / \mathrm{min}$ for $5 \mathrm{~min}$. The 
A

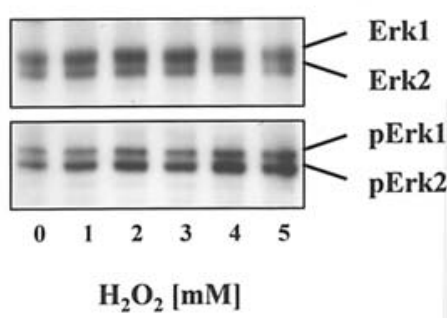

B

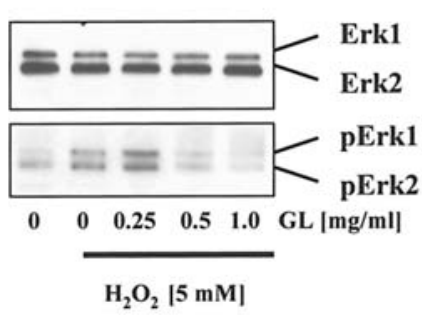

Figure 1. G. lucidum inhibits oxidative stress-induced activation of Erk1/2. (A) Phosphorylation of Erk1/2 was determined in MCF-7 cells treated with 0$5 \mathrm{mM} \mathrm{H}_{2} \mathrm{O}_{2}$ for $30 \mathrm{~min}$. Whole cell extracts were prepared, and subjected to Western blot analysis with anti-Erk1/2, anti-phospho-Erk1/2 antibodies as described in Materials and methods. The results are representative of three separate experiments. (B) MCF-7 cells were pretreated with $0-1.0 \mathrm{mg} / \mathrm{ml}$ of G. lucidum extract (GL) for $24 \mathrm{~h}$, followed by treatment with $5 \mathrm{mM} \mathrm{H} \mathrm{H}_{2} \mathrm{O}_{2}$ for $30 \mathrm{~min}$. Phosphorylation of Erk1/2 was determined as described above. The results are representative of three separate experiments.

enrichment column was then switched into the micro flow path and further separated on C-18 reversed phase ZORBAX 300SB-C18 (0.5x150 mm; Agilent) capillary column coupled with the electrospray ionization (ESI) source of ion trap mass spectrometer (XCT Plus, Agilent). The mobile phases consisted of $0.01 \%$ TFA in water (X) and acetonitrile (Y) (0 min: $\mathrm{X}=97 \%, \mathrm{Y}=3 \% ; 10 \mathrm{~min}: \mathrm{X}=97 \%, \mathrm{Y}=3 \% ; 15 \mathrm{~min}: \mathrm{X}=15 \%$, $\mathrm{Y}=85 \%$; 50 min: $\mathrm{X}=75 \%, \mathrm{Y}=25 \%$; $55 \mathrm{~min}: \mathrm{X}=0, \mathrm{Y}=100 \%$; 60 min: $X=0 \%, Y=100 \%$; $61 \min : X=97 \%, Y=3 \%$; hold to $71 \mathrm{~min}$ ) with a flow rate of $4 \mu \mathrm{l} / \mathrm{min}$. The system was controlled by ChemStation software (Agilent). LC-ESI-MS chromatograms were acquired in positive ion mode under the following conditions: a capillary voltage of $3500 \mathrm{~V}$ and an end plate offset of $500 \mathrm{~V}$. The dry temperature was set at $325^{\circ} \mathrm{C}$. Dry gas flow was maintained at $5 \mathrm{l} / \mathrm{min}$. Acquisition range was $250-1000 \mathrm{~m} / \mathrm{z}$ with a $0.2-\mathrm{sec}$ accumulation time and scan speed of $8,100 \mathrm{~m} / \mathrm{z} / \mathrm{sec}$.

Statistical analysis. Data are presented as means \pm SD. Statistical comparison between groups of data was carried out using the Student's t-test. $\mathrm{p}<0.005$ was considered to be significant.

\section{Results}

G. lucidum inhibits oxidative stress-induced activation of Erk1/2 in non-invasive breast cancer cells. We have previously demonstrated that an extract from medicinal mushroom G. lucidum inhibits the migration of highly invasive human breast cancer cells (29). Recent reports demonstrate that cell migration of cardiomyocytes and hepatocytes can be induced by oxidative stress through the activation of extracellular regulated kinases (Erk1/2) $(30,31)$. In order to evaluate if oxidative stress activates Erk1/2 in poorly invasive breast cancer cells, we treated MCF-7 cells with hydrogen peroxide $\left(\mathrm{H}_{2} \mathrm{O}_{2}\right)$. As seen in Fig. 1A, $\mathrm{H}_{2} \mathrm{O}_{2}(1-5 \mathrm{mM})$ markedly increased phosphorylation of Erk1/2 in a dose-dependent manner with maximum levels of pErk1/2 after 30 min of incubation. In agreement with previous reports demonstrating antioxidative properties of G. lucidum (23-25), $\mathrm{H}_{2} \mathrm{O}_{2}$-induced oxidative stress in MCF-7 cells was also inhibited by G. lucidum, as demonstrated by the inhibition of lipid peroxidation (data not shown). In order to evaluate if this antioxidative effect is mediated through the inhibition of activation of Erk1/2, MCF-7 cells were treated with G. lucidum for $24 \mathrm{~h}$, followed by $\mathrm{H}_{2} \mathrm{O}_{2}$ incubation for $30 \mathrm{~min}$. As seen in Fig. 1B, G. lucidum markedly suppressed the phosphorylation of Erk $1 / 2$ in a dose-response manner. Therefore, G. lucidum posseses antioxidative properties and inhibits activation of Erk1/2 in breast cancer cells.

G. lucidum inhibits oxidative-stress induced activation of $A P-1$ and $N F-\kappa B$. Erk1/2 induces activity of transcription factor activator protein-1 (AP-1), which consists of homo- and heterodimers of Jun and Fos protein subfamilies (13). As shown above, oxidative-stress-induced activation of Erk $1 / 2$ was abolished by G. lucidum. Therefore, we evaluated the effect of $G$. lucidum on the expression of AP-1 subunits, c-Jun and c-Fos, in breast cancer cells exposed to oxidative stress. MCF-7 cells were treated with vehicle or G. lucidum for $24 \mathrm{~h}$, followed by treatment with $\mathrm{H}_{2} \mathrm{O}_{2}$ for 0-24 h. As shown in Fig. 2A, $\mathrm{H}_{2} \mathrm{O}_{2}$ induced expression of c-Fos in a time-dependent manner with maximum induction after $6 \mathrm{~h}$ of $\mathrm{H}_{2} \mathrm{O}_{2}$ treatment (data for longer exposure not shown), and G. lucidum markedly down-regulated its expression. Although $\mathrm{H}_{2} \mathrm{O}_{2}$ treatment did not further induce expression of c-Jun in MCF-7 cells, the constitutive expression of c-Jun was also inhibited by $G$. lucidum (Fig. 2A). In order to examine if the down-regulation of expression of c-Fos and c-Jun by G. lucidum modulates the transcriptional activity of AP-1, MCF-7 cells were transfected with AP-1-Luc reporter gene construct, and treated with $G$. lucidum and $\mathrm{H}_{2} \mathrm{O}_{2}$. In agreement with the oxidative stressinduced expression of c-Fos, $\mathrm{H}_{2} \mathrm{O}_{2}$ also induced AP-1 activity in MCF-7 cells, and G. lucidum significantly inhibited this activity (Fig. 2B). Furthermore, G. lucidum also inhibited the $\mathrm{H}_{2} \mathrm{O}_{2}$-dependent DNA-binding of AP-1 in gel-shift analysis (data not shown). Since the oxidative stress has been linked to the activation of NF-кB $(16,32)$, and we have previously demonstrated that $G$. lucidum inhibits constitutively active NF-кB in MDA-MB-231 cells (27), we evaluated the effect of G. lucidum on the oxidative stress-induced NF-кB activity. MCF-7 cells were transfected with NF-кB-1-Luc reporter gene construct, and treated with G. lucidum and $\mathrm{H}_{2} \mathrm{O}_{2}$. As shown in Fig. $2 \mathrm{C}, \mathrm{H}_{2} \mathrm{O}_{2}$ induced the activity of $\mathrm{NF}-\mathrm{kB}$, whereas treatment with $G$. lucidum markedly suppressed this activity. In addition, we observed the same effect in the NF-кB DNA-binding assay (data not shown). Therefore, G. lucidum protects against oxidative stress induced activation of AP-1 and NF- $\mathrm{KB}$ in breast cancer cells. 
A

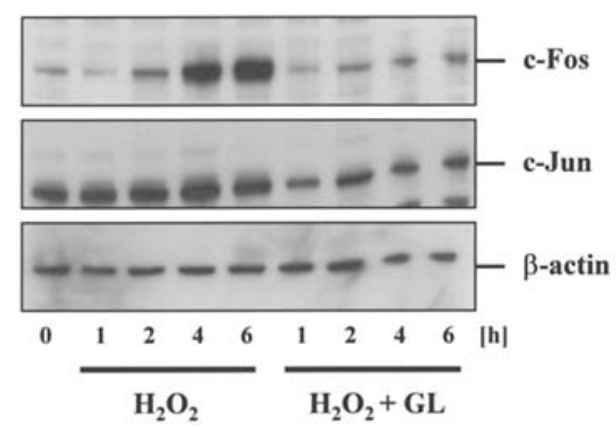

B
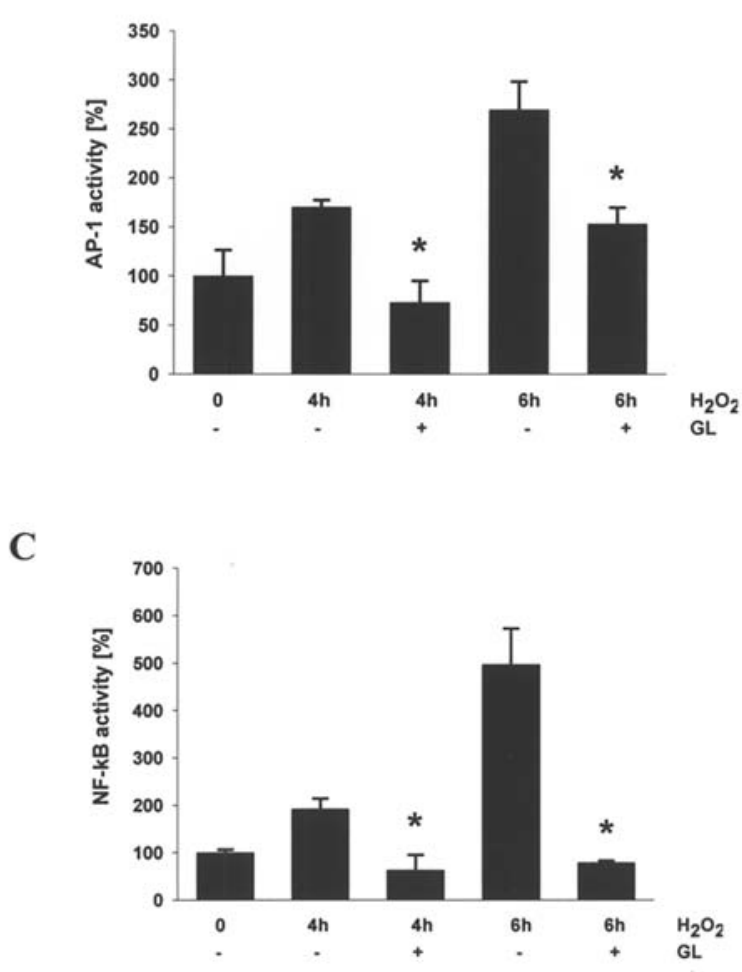

Figure 2. G. lucidum inhibits oxidative stress-induced activation of AP-1 and NF- $\mathrm{NB}$ in MCF-7 cells. (A) The expression of c-Fos and c-Jun was determined in MCF-7 cells treated with G. lucidum extract (GL, $0.5 \mathrm{mg} / \mathrm{ml}$ ), followed by incubation with $5 \mathrm{mM} \mathrm{H}_{2} \mathrm{O}_{2}$ for $0-6 \mathrm{~h}$. Whole cell extracts were prepared, and subjected to Western blot analysis with anti-c-Fos and anti-cJun antibodies as described in Materials and methods. The equal loading was confirmed by Western blotting with anti- $\beta$-actin antibody. The results are representative of three separate experiments. (B) AP-1 activity was assessed in MCF-7 cells transfected with AP-1-Luc reporter construct and B-galactosidase expression vector, pretreated for $24 \mathrm{~h}$ with vehicle or G. lucidum extract (GL, $0.5 \mathrm{mg} / \mathrm{ml}$ ) followed by incubation with $5 \mathrm{mM} \mathrm{H}_{2} \mathrm{O}_{2}$ for 4 and $6 \mathrm{~h}$ as described in Materials and methods. The results are expressed as the percentage of relative AP-1 activity. Each bar represents the mean $\pm \mathrm{SD}$ of 3-6 transfection experiments. ${ }^{*} \mathrm{p}<0.005 \mathrm{H}_{2} \mathrm{O}_{2}$ vs GL. (C) NF- $\mathrm{kB}$ activity was assessed in MCF-7 cells transfected with NF- $\mathrm{BB}-\mathrm{Luc}$ reporter construct and B-galactosidase expression vector, pretreated for $24 \mathrm{~h}$ with vehicle or G. lucidum extract (GL, $0.5 \mathrm{mg} / \mathrm{ml}$ ) followed by incubation with $5 \mathrm{mM}$ $\mathrm{H}_{2} \mathrm{O}_{2}$ for 4 and $6 \mathrm{~h}$ as described in Materials and methods. The results are expressed as the percentage of relative NF- $\mathrm{NB}$ activity. ${ }^{*} \mathrm{p}<0.005 \mathrm{H}_{2} \mathrm{O}_{2}$ vs GL.

G. lucidum suppresses oxidative stress-induced secretion of $I L-8$. Because the expression of IL-8 is controlled by AP-1 and NF-кB $(11,12)$, which is inhibited by $G$. lucidum, we
$\mathbf{A}$

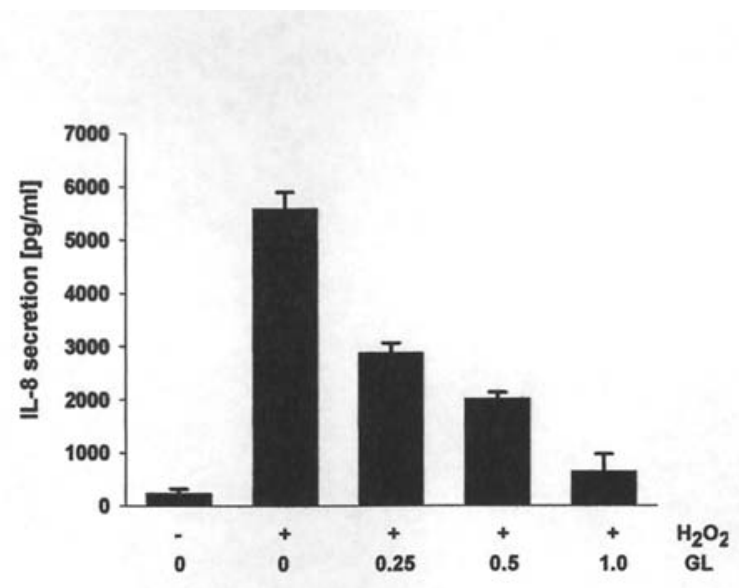

B

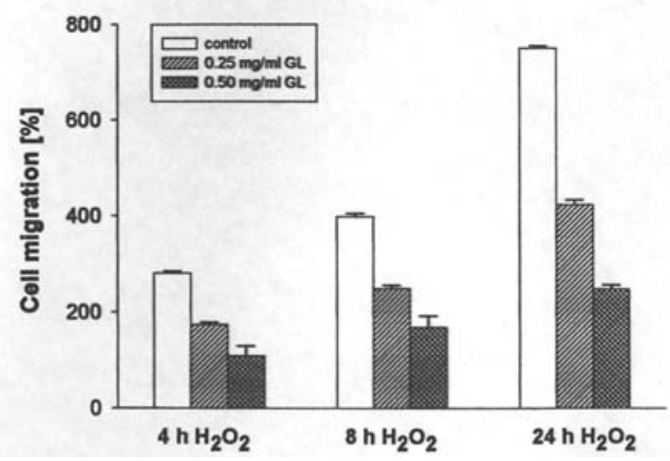

Figure 3. G. lucidum suppresses oxidative stress-induced migration of MCF-7 cells through the inhibition of secretion of IL-8. (A) MCF-7 cells were treated with vehicle or G. lucidum extract (GL, $0.5 \mathrm{mg} / \mathrm{ml}$ ) for $24 \mathrm{~h}$, followed by incubation with $5 \mathrm{mM} \mathrm{H}_{2} \mathrm{O}_{2}$ for another $24 \mathrm{~h}$. The media were collected and the IL-8 secretion determined as described in Materials and methods. The results are representative of three separate experiments. (B) Migration of MCF-7 cells toward conditioned media from MCF-7 cells treated with G. lucidum extract (GL, 0-0.5 mg/ml) for $24 \mathrm{~h}$, followed by incubation with $5 \mathrm{mM} \mathrm{H}_{2} \mathrm{O}_{2}$ for 4,8 and $24 \mathrm{~h}$ was assessed as described in Materials and methods. The results are representative of three separate filters repeated at least twice.

hypothesized that G. lucidum will suppress secretion of IL-8 from breast cancer cells exposed to oxidative stress. MCF-7 cells were treated with G. lucidum for $24 \mathrm{~h}$ followed by incubation with $\mathrm{H}_{2} \mathrm{O}_{2}$ for 0-24 h. As expected, oxidative stress induced secretion of IL- 8 from MCF-7 cells in a timedependent manner, and the secretion of IL- 8 was inhibited by G. lucidum (Fig. 3A). As recently reported, the expression of IL-8 was associated with enhanced migratory potential and invasiveness of metastatic breast cancer cells (33). Since oxidative stress induces secretion of IL-8 from MCF-7 cells, we evaluated if $\mathrm{H}_{2} \mathrm{O}_{2}$ stimulates migration of these nonmetastatic cells and if G. lucidum can inhibit oxidative stressinduced migration of MCF-7 cells. Media from MCF-7 cells, pretreated with $G$. lucidum for $24 \mathrm{~h}$, followed by incubation with $\mathrm{H}_{2} \mathrm{O}_{2}$ for 4,8 and $24 \mathrm{~h}$, were collected and concentrated. Migration of MCF-7 cells toward conditioned media was assessed as described under Materials and methods. As 

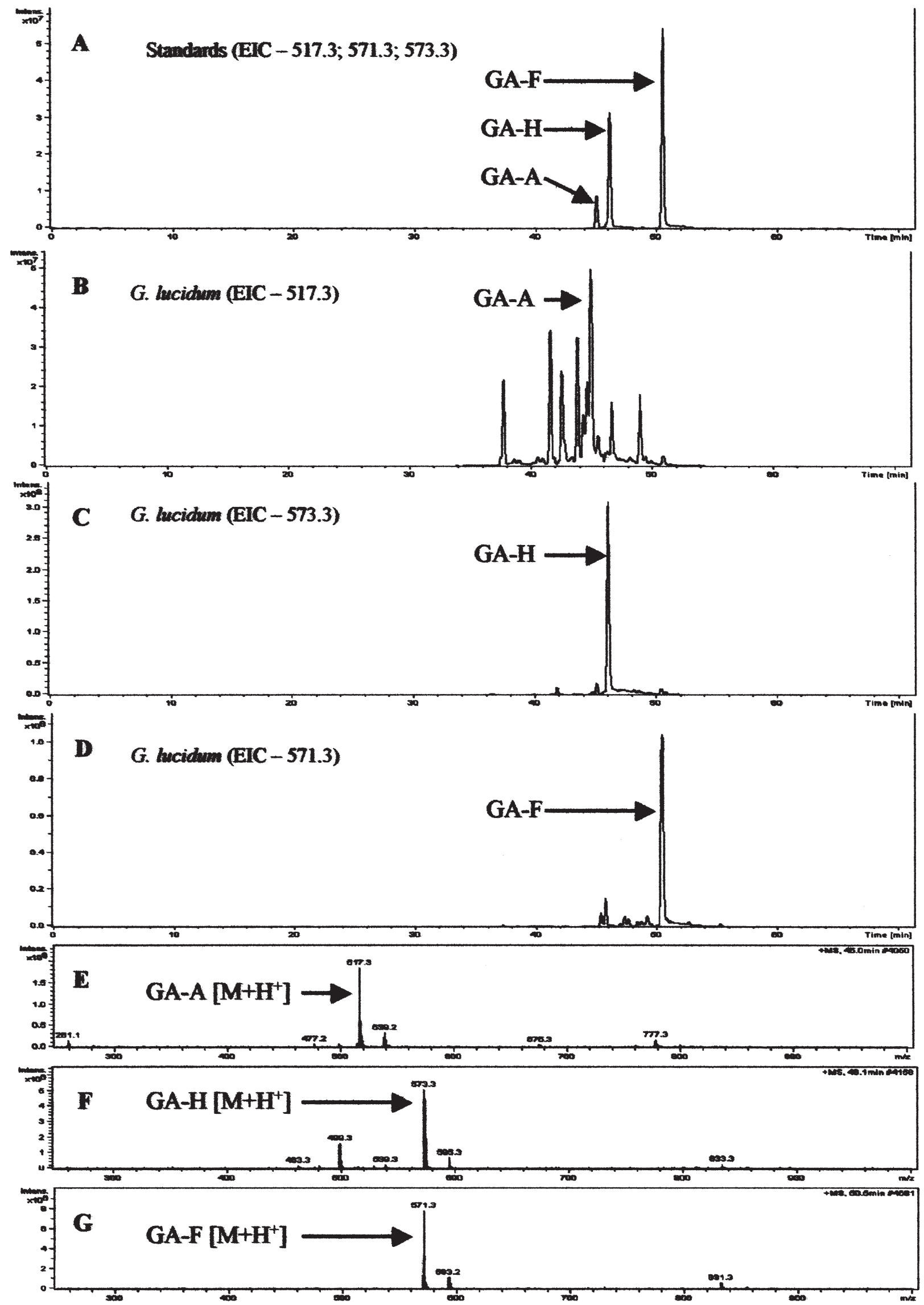

Figure 4. Identification of ganoderic acid A, F, and $\mathrm{H}$ in G. lucidum extract by microLC-ESI-MS. (A) Extracted ion chromatogram at m/z 517.3, 571.3, and 573.3 corresponding to ganoderic acid A (GA-A), ganoderic acid F (GA-F) and ganoderic acid H (GA-H) standards (50 ng each). (B) Extracted ion chromatogram at m/z 517.3 in G. lucidum. (C) Extracted ion chromatogram at m/z 573.3 in G. lucidum. (D) Extracted ion chromatogram at m/z 571.3 in $G$. lucidum. (E) MS spectrum of extracted peak corresponding to GA-A standard. (F) MS spectrum of extracted peak corresponding to GA-H standard. (G) MS spectrum of extracted peak corresponding to GA-F standard. 
shown in Fig. 3B, conditioned media from $\mathrm{H}_{2} \mathrm{O}_{2}$-treated cells induced migration of MCF-7 cells in a time-response manner, whereas pre-treatment with G. lucidum inhibits oxidative stress-induced migration in a dose-response manner. These collective results suggest that G. lucidum suppressed oxidative stress-induced secretion of IL-8 resulting in the inhibition of oxidative stress-induced migration of breast cancer cells.

$G$. lucidum contains ganoderic acids $A, F$ and $H$. The antioxidant properties of $G$. lucidum are generally attributed to polysaccharides and triterpenes (23-26). However, the amount of biologically active compounds in G. lucidum extract may vary and depends on the strain of G. lucidum, place of production, cultivation conditions, and extraction procedures (34). Although the G. lucidum used in our study contained $6 \%$ of triterpenes and $13.5 \%$ of polysaccharides, further analysis is necessary for the standardization of this extract. Ganoderic acid A was previously identified in the G. lucidum triterpene fraction with antioxidant properties (26). Therefore, we used commercially available isolated ganoderic acids $\mathrm{A}, \mathrm{F}$ and $\mathrm{H}$ for the standardization of G. lucidum extract by microLCESI-MS analysis. Fig. 4 shows the extracted ion chromatogram of standard mixture corresponding to the protonated ions of ganoderic acid $\mathrm{A}, \mathrm{F}$, and $\mathrm{H}$. Major peaks with ions at $\mathrm{m} / \mathrm{z}$ $517.3,571.3$, and 573.3 corresponding to ganoderic acid A (GA-A), ganoderic acid $\mathrm{F}(\mathrm{GA}-\mathrm{F})$ and ganoderic acid $\mathrm{H}$ (GA-H) were observed at retention times of 45.0, 50.5, and $46.1 \mathrm{~min}$, respectively (Fig. 4A and E-G). G. lucidum extract after solid phase extraction (corresponding to $250 \mu \mathrm{g}$ of dry powder) was analyzed in the same way. Extracted ion chromatogram at m/z 517.3 showed several major chromatographic peaks with retention times between 37 and 52 min (Fig. 4B) indicating the presence of multiple compounds with that particular m/z. Ganoderic acid A was identified, however, by comparison of corresponding retention time of standard at $45.0 \mathrm{~min}$ (Fig. 4A). Extracted ion chromatogram at m/z 571.3 (Fig. 4D) and m/z 573.3 (Fig. 4C) revealed major single peaks at retention times of 50.5 , and $46.1 \mathrm{~min}$, respectively, indicating the presence of ganoderic acid $\mathrm{F}$ and ganoderic acid H. By comparison of corresponding peak intensities in sample to peak intensities of standards in amounts of 5, 50 and $500 \mathrm{ng}$ we estimated concentrations of GA-A, GA-F, and GA-H at $1.8,0.5$, and $3.0 \mathrm{mg} / 1 \mathrm{~g}$ dry powder, respectively. In summary, the analysis of specific ganoderic acids by LC-ESIMS is a useful tool for the characterization and standardization of G. lucidum.

\section{Discussion}

Epidemiological and experimental studies suggest that some dietary antioxidants may have preventive and/or therapeutic effects against cancer. G. lucidum is a popular medicinal mushroom, which has been used for the treatment of a variety of diseases in traditional Chinese medicine. In addition to their anticancer effects, polysaccharide and triterpene extracts from G. lucidum also exhibited antioxidative activity (23-26). In the present study, we demonstrate that G. lucidum suppressed oxidative stress-induced invasiveness of breast cancer cells. Therefore, G. lucidum inhibits oxidative stress-induced phosphorylation of Erk1/2, followed by the inhibition of transcriptional activity of $\mathrm{AP}-1$ and $\mathrm{NF}-\kappa \mathrm{B}$, leading to the suppression of secretion of IL-8, and finally resulting in the inhibition of migration of breast cancer cells.

We show that oxidative stress, mediated through $\mathrm{H}_{2} \mathrm{O}_{2}$, stimulated Erk1/2 phosphorylation (activation) in poorly invasive breast cancer cells. Furthermore, we show that $G$. lucidum inhibits $\mathrm{H}_{2} \mathrm{O}_{2}$-induced phosphorylation of Erk1/2. However, induction of Erk1/2 activity by G. lucidum polysaccharide extract was demonstrated by Hsu et al (35) in macrophages, and associated with the up-regulation of expression of inflammatory cytokine IL-1. Cheung et al (36) also demonstrated Erk1/2 activation by G. lucidum polysaccharide extract in PC12 neuron cells, which was linked to the neuronal differentiation. Interestingly, Li et al (37) showed the activation of Erk1/2 by triterpene, ganoderic acid X isolated from $G$. lucidum. This activation of Erk1/2 was associated with the inhibition of topoisomerase activity and induction of apoptosis of hepatoma cells (37). Our data, demonstrating the opposite effect, inhibition of Erk1/2 activity by G. lucidum, can be explained by the effect on different cell lines and/or modulating the different signaling pathways in different environments. In addition, oxidative stress $\left(\mathrm{H}_{2} \mathrm{O}_{2}\right)$ stimulates Erk1/2 activation $(30,38)$, and we and others have described the antioxidative effect of G. lucidum extracts containing polysaccharides, triterpenes or both (23-26). Finally, we have recently demonstrated that $G$. lucidum suppresses constitutively active Erk1/2 in prostate cancer cells (39).

Here, we also demonstrate that G. lucidum suppressed oxidative stress-induced activation of downstream targets of Erk1/2, transcription factors AP-1 and NF- $\mathrm{BB}$. The central molecule in the inhibition of AP-1 and NF-кB activity is c-Fos, whose oxidative stress-induced expression was down-regulated by G. lucidum. Therefore, AP-1 activity can be regulated directly through its subunit c-Fos or indirectly through NF-кB, which regulates expression of c-Fos (40). Although we have recently demonstrated the inhibition of constitutively active AP-1 and NF-кB by G. lucidum in cancer cells $(27,39)$, other reports described activation as well as inhibition of NF- $\mathrm{KB}$ in different systems. Therefore, Kuo et al (41) recently reported that mycelia from $G$. lucidum activated NF- $\mathrm{KB}$ in macrophages, and Lin et al (42) demonstrated the induction of NF-кB in dendritic cells by $G$. lucidum polysaccharides. On the other hand, Zhang et al (43) showed inhibition of NF-кB by $G$. lucidum polysaccharides in alloxan-induced pancreatic islets. In agreement with our data, Zhao et al (44) recently demonstrated that G. lucidum triterpenes protect against hypoxia/ reoxygenation injury through the suppression of nuclear translocation of NF-кB.

In the present study, we also demonstrate that G. lucidum suppressed oxidative stress-induced secretion of IL-8 from breast cancer cells. Our results are in agreement with a recent report by Lai et al (45) demonstrating down-regulation of IL-8 expression by $G$. lucidum in tubular epithelial cells exposed to oxidative damage. At the functional level, we found that oxidative stress induced the migratory potential of poorly invasive breast cancer cells MCF-7. This effect is mediated by the secreted IL-8, whose expression is stimulated by $\mathrm{H}_{2} \mathrm{O}_{2}$ through Erk1/2 signaling including the activation of AP-1 and NF- $\mathrm{B}(46,47)$. The stimulation of migration with a low concentration of $\mathrm{H}_{2} \mathrm{O}_{2}(0.1-5 \mu \mathrm{M})$ was recently demonstrated in melanoma and prostate cancer cells $(48,49)$. The low con- 
centration of $\mathrm{H}_{2} \mathrm{O}_{2}$ is mediated through thioredoxin signaling in melanoma cells (48), and through the activation of heparin affin regulatory peptide (HARP) in prostate cancer cells (49). However, we used a high concentration of $\mathrm{H}_{2} \mathrm{O}_{2}(5 \mathrm{mM})$ for the stimulation of Erk1/2 signaling in MCF-7 cells. Thus, our data are in agreement with previous reports demonstrating the induction of Erk1/2 activity by $1-10 \mathrm{mM} \mathrm{H}_{2} \mathrm{O}_{2}(30,38)$. Furthermore, Erk-dependent pathway was recently linked to the stimulation of migration of MCF-7 cells (50). Finally, we show that oxidative stress-induced and IL-8-dependent cell migration is suppressed by G. lucidum. We have also previously demonstrated the inhibition of unstimulated migration of highly invasive breast and prostate cancer cells through the suppression of constitutive secretion of urokinase plasminogen activator (uPA) (28).

The major obstacle for the acceptance of the extracts from natural products in Western medicine is their complexity and absent standardization of biologically active compounds. This complexity can also bring significant advantages as is the reduction of cytotoxicity of certain components and/or modulation of unrelated signaling by different compounds, which can possess a synergistic effect (51). In addition, the standardization of G. lucidum is crucial for its characterization since the composition and amount of biologically active triterpenes and polysaccharides depend on the place of production, cultivation conditions, extraction procedure and the strain of G. lucidum (36). Furthermore, we recently demonstrated that some extracts of G. lucidum proved to have strong activity against cancer cells, whereas other extracts did not show any effect (52). Therefore, we evaluated the $G$. lucidum used in this and our previous studies for the presence and amount of three different ganoderic acids. Since this extract demonstrates strong anti-cancer activity in vitro, this evaluation could be helpful for the standardization of other G. lucidum extracts.

In conclusion, oxidative stress markedly stimulated the migratory potential of poorly invasive breast cancer cells MCF-7 through the activation of Erk signaling resulting in the secretion of pro-migratory chemokine IL-8. However, G. lucidum inhibited this signaling and suppressed oxidative stress-induced migration of breast cancer cells. These results implicate G. lucidum as a potential chemopreventive and/or therapeutic natural product, which may stop invasion and metastasis of breast cancer. Further studies are necessary to confirm this preventative/therapeutic potential of G. lucidum extract in vivo.

\section{Acknowledgements}

This work was supported by a grant from the Methodist Health Foundation to D.S. We also thank Veronika Slivova for her technical assistance, and Pharmanex LLC for providing us with the G. lucidum extract.

\section{References}

1. Jemal A, Murray T, Ward E, Samuels A, Tiwari RC, Ghafoor A, Feuer EJ and Thun MJ: Cancer statistics. CA Cancer J Clin 55: 10-30, 2005.

2. Brown NS and Bicknell R: Hypoxia and oxidative stress: its effects on growth, metastatic potential and response to therapy of breast cancer. Breast Cancer Res 3: 323-327, 2001.
3. Brown NS, Jones A, Fujiyama C, Harris AL and Bicknell R: Thymidine phosphorylase induces carcinoma cell oxidative stress and promotes secretion of angiogenic factors. Cancer Res 60: 6298-6302, 2000 .

4. Heidemann J, Ogawa H, Dwinell MB, Rafiee P, Maaser C, Gockel HR, Otterson MF, Ota DM, Lugering N, Domschke W and Binion DG: Angiogenic effects of interleukin 8 (CXCL8) in human intestinal microvascular endothelial cells are mediated by CXCR2. J Biol Chem 278: 8508-8515, 2003.

5. Rennekampff HO, Hansbrough JF, Kiessig V, Dore C, Sticherling $M$ and Schroder JM: Bioactive interleukin- 8 is expressed in wounds and enhances wound healing. J Surg Res 93: 41-54, 2000

6. Singh RK and Varney ML: IL-8 expression in malignant melanoma: implications in growth and metastasis. Histol Histopathol 15: 843-849, 2000.

7. Green AR, Green VL, White MC and Speirs V: Expression of cytokine messenger RNA in normal and neoplastic human breast tissue: identification of interleukin- 8 as a potential regulatory factor in breast tumours. Int J Cancer 72: 937-941, 1997.

8. Freund A, Chauveau C, Brouillet JP, Lucas A, Lacroix M, Licznar A, Vignon F and Lazannec G: IL-8 expression and its possible relationship with estrogen-receptor-negative status of breast cancer cells. Oncogene 22: 256-265, 2003.

9. De Larco JE, Wuertz BR, Rosner KA, Erickson SA, Gamache DE, Manivel JC and Furcht LT: A potential role for interleukin- 8 in the metastatic phenotype of breast carcinoma cells. Am J Pathol 158: 639-646, 2001.

10. Bendre MS, Gaddy-Kurten D, Mon-Foote T, Akel NS, Skinner RA, Nicholas RW and Suva LJ: Expression of interleukin 8 and not parathyroid hormone-related protein by human breast cancer cells correlates with bone metastasis in vivo. Cancer Res 62: 5571-5579, 2002.

11. Kunsch C, Lang RK, Rosen CA and Shannon MF: Synergistic transcriptional activation of the IL- 8 gene by NF-kappa B p65 (RelA) and NF-IL-6. J Immunol 153: 153-164, 1994.

12. Yasumoto K, Okamoto S, Mukaida N, Murakami S, Mai M and Matsushima K: Tumor necrosis factor alpha and interferon gamma synergistically induce interleukin 8 production in a human gastric cancer cell line through acting concurrently on AP-1 and NF-кB-like binding sites of the interleukin 8 gene. J Biol Chem 267: 22506-22511, 1992.

13. Shaulian E and Karin M: AP-1 as a regulator of cell life and death. Nature Cell Biol 4: E131-E136, 2002.

14. Mayo MW and Baldwin AS: The transcription factor $\mathrm{NF}-\kappa \mathrm{B}$ : control of oncogenesis and cancer therapy resistance. Biochim Biophys Acta 1470: M55-M62, 2000.

15. Schiff R, Reddy P, Ahotupa M, Coronado-Heinsohn E, Grim M, Hilsenbeck SG, Lawrence R, Deneke S, Herrera R, Chamness GC, Fuqua SA, Brown PH and Osborne CK: Oxidative stress and AP-1 activity in tamoxifen-resistant breast tumors in vivo. $\mathrm{J}$ Natl Cancer Inst 23: 1926-1934, 2000.

16. Ripple MO, Henry WF, Schwarze SR, Wilding G and Weindruch R: Effect of antioxidants on androgen-induced AP-1 and NF-kappaB DNA-binding activity in prostate carcinoma cells. J Natl Cancer Inst 91: 1227-1232, 1999.

17. Sen CK and Packer L: Antioxidant and redox regulation of gene transcription. FASEB J 10: 709-720, 1996.

18. Zhang Y and Chen F: Reactive oxygen species (ROS), troublemakers between nuclear factor-kappaB (NF-kappaB) and c-Jun $\mathrm{NH}(2)$-terminal kinase (JNK). Cancer Res 64: 1902-1905, 2004.

19. Greenwald P, Clifford CK and Milner JA: Diet and cancer prevention. Eur J Cancer 37: 948-965, 2001.

20. Borek C: Dietary antioxidants and human cancer. Integr Cancer Ther 3: 333-341, 2004.

21. Yuen JWM and Gohel MDI: Anticancer effects of Ganoderma lucidum: a review of scientific evidence. Nutr Cancer 53: 11-17, 2005.

22. Lin ZB: Cellular and molecular mechanisms of immunomodulation by Ganoderma lucidum. J Pharmacol Sci 99: 144-153, 2005.

23. Kim HS, Kacew S and Lee BM: In vitro chemopreventive effects of plant polysaccharides (Aloe barbadensis miller, Lentinus edodes, Ganoderma lucidum and Coriolus versicolor). Carcinogenesis 20: 1637-1640, 1999.

24. Lee JM, Kwon H, Jeong H, Lee JW, Lee SY, Baek SJ and Surh YJ: Antioxidant and anti-tumor promoting activities of the methanol extract of heat-processed ginseng. Cancer Lett 150: 41-48, 2000 
25. Mau JL, Lin HC and Chen CC: Antioxidant properties of several medicinal mushrooms. J Agric Food Chem 50: 6072-6077, 2002.

26. Zhu M, Chang Q, Wong LK, Chong FS and Li RC: Triterpene antioxidants from Ganoderma lucidum. Phytother Res 13: 529-531, 1999.

27. Jiang J, Slivova V, Harvey K, Valachovicova T and Sliva D: Ganoderma lucidum suppresses growth of breast cancer cells through the inhibition of Akt/NF-kB signaling. Nutr Cancer 49: 209-216, 2004.

28. Sliva D, Labarrere C, Slivova V, Sedlak M, Lloyd FP Jr and Ho NWY: Ganoderma lucidum suppresses motility of highly invasive breast and prostate cancer cells. Biochem Biophys Res Commun 298: 603-612, 2002

29. Slivova V, Valachovicova T, Jiang J and Sliva D: Ganoderma lucidum inhibits invasiveness of breast cancer cell. J Cancer Integr Med 2: 25-30, 2004

30. Fukuzawa J, Nishihira J, Hasebe N, Haneda T, Osaki J, Saito T, Nomura T, Fujino T, Wakamiya N and Kikuchi K: Contribution of macrophage migration inhibitory factor to extracellular signalregulated kinase activation by oxidative stress in cardiomyocytes. J Biol Chem 277: 24889-24895, 2002.

31. Novo E, Marra EF, Zamara E, Valfre di Bonzo L, Caligiuri A, Cannito S, Antonaci C, Colombatto S, Pinzani M and Parola M: Dose dependent and divergent effects of superoxide anion on cell death, proliferation, and migration of activated human hepatic stellate cells. Gut 55: 90-97, 2006.

32. Meyskens FL Jr, Buckmeier JA, McNulty SE and Tohidian NB: Activation of nuclear factor-kappa $B$ in human metastatic melanoma cells and the effect of oxidative stress. Clin Cancer Res 5: 1197-1202, 1999.

33. Kim SW, Hayashi M, Lo JF, Fearns C, Xiang R, Lazennec G, Yang $\mathrm{Y}$ and Lee JD: Tid1 negatively regulates the migratory potential of cancer cells by inhibiting the production of interleukin-8. Cancer Res 65: 8784-8791, 2005.

34. Hattori M: Recent studies on the bitter principles of Ganoderma lucidum - isolation of novel triterpenes, their biological activity and pharmacokinetics. Proc Intl Symposium Ganoderma Sci Auckland, 27-29 April 2001.

35. Hsu HY, Hua KF, Lin CC, Lin CH, Hsu J and Wong CH: Extract of Reishi polysaccharides induces cytokine expression via TLR4-modulated protein kinase signaling pathways. J Immunol 173: 5989-5999, 2004.

36. Cheung WM, Hui WS, Chu PW, Chiu SW and Ip NY: Ganoderma extract activates MAP kinases and induces the neuronal differentiation of rat pheochromocytoma PC12 cells. FEBS Lett 486: 291-296, 2000.

37. Li CH, Chen PY, Chang UM, Kan LS, Fang WH, Tsai KS and Lin SB: Ganoderic acid X, a lanostanoid triterpene, inhibits topoisomerases and induces apoptosis of cancer cells. Life Sci 77: 252-265, 2005 .

38. Aikawa R, Komuro I, Yamazaki T, Zou Y, Kudoh S, Tanaka M, Shiojima I, Hiroi Y and Yazaki Y: Oxidative stress activates extracellular signal-regulated kinases through Src and Ras in cultured cardiac myocytes of neonatal rats. J Clin Invest 100: 1813-1821, 1997.

39. Stanley G, Harvey K, Slivova V, Jiang J and Sliva D: Ganoderma lucidum suppresses angiogenesis through the inhibition of secretion of VEGF and TGF-beta1 from prostate cancer cells. Biochem Biophys Res Commun 330: 46-52, 2005.
40. Fujioka S, Niu J, Schmidt C, Sclabas GM, Peng B, Uwagawa T, $\mathrm{Li}$ Z, Evans DB, Abbruzzese JL and Chiao PJ: NF-kB and AP-1 connection: mechanism of NF- $\mathrm{kB}$-dependent regulation of AP-1 activity. Mol Cell Biol 24: 7806-7819, 2004.

41. Kuo MC, Weng CY, Ha CL and Wu MJ: Ganoderma lucidum mycelia enhance innate immunity by activating NF-kappaB. J Ethnopharmacol 103: 217-222, 2006.

42. Lin YL, Liang YC, Lee SS and Chiang BL: Polysaccharide purified from Ganoderma lucidum induced activation and maturation of human monocyte-derived dendritic cells by the NF-kappaB and p38 mitogen-activated protein kinase pathways. J Leukoc Biol 78: 533-543, 2005.

43. Zhang HN, He JH, Yuan L and Lin ZB: In vitro and in vivo protective effect of Ganoderma lucidum polysaccharides on alloxan-induced pancreatic islets damage. Life Sci 73: 2307-2319, 2003.

44. Zhao HB, Wang SZ, He OH, Yuan L, Chen AF and Lin ZB: Ganoderma total sterol (GS) and GS1 protect rat cerebral cortical neurons from hypoxia/reoxygenation injury. Life Sci 76: 1027-1037, 2005.

45. Lai KN, Chan LY, Tang SC and Leung JC: Ganoderma extract prevents albumin-induced oxidative damage and chemokines synthesis in cultured human proximal tubular epithelial cells. Nephrol Dial Transplant 21: 1188-1197, 2006.

46. Hwang YS, Jeong M, Park JS, Kim MH, Lee DB, Shin BA, Mukaida N, Ellis LM, Kim HR, Ahn BW and Jung YD: Interleukin-1beta stimulates IL-8 expression through MAP kinase and ROS signaling in human gastric carcinoma cells. Oncogene 23: 6603-6611, 2004.

47. Lakshminarayanan V, Drab-Weiss EA and Roebuck KA: $\mathrm{H}_{2} \mathrm{O}_{2}$ and tumor necrosis factor-alpha induce differential binding of the redox-responsive transcription factors AP-1 and NF-kappaB to the interleukin-8 promoter in endothelial and epithelial cells. J Biol Chem 273: 32670-32678, 1998.

48. Cheng GC, Schulze PC, Lee RT, Sylvan J, Zetter BR and Huang $\mathrm{H}$ : Oxidative stress and thioredoxin-interacting protein promote intravasation of melanoma cells. Exp Cell Res 300: 297-307, 2004.

49. Polytarchou C, Hatziapostolou M and Papadimitriou E: Hydrogen peroxide stimulates proliferation and migration of human prostate cancer cells through activation of activator protein-1 and upregulation of the heparin affin regulatory peptide gene. J Biol Chem 280: 40428-40435, 2005.

50. Lester RD, Jo M, Campana WM and Gonias SL: Erythropoietin promotes MCF-7 breast cancer cell migration by an ERK/ mitogen-activated protein kinase-dependent pathway and is primarily responsible for the increase in migration observed in hypoxia. J Biol Chem 280: 39273-39277, 2005.

51. Williamson EM: Synergy and other interactions in phytomedicines. Phytomedicine 8: 401-409, 2001.

52. Sliva D, Sedlak M, Slivova V, Valachovicova T, Lloyd FP Jr and Ho NWY: Biologic activity of Ganoderma lucidum for the inhibition of highly invasive breast and prostate cancer cells. J Altern Complement Med 9: 491-497, 2003. 